\title{
EVALUATION OF EFFICACY OF PASTEURIA PENETRANS ALONE AND IN COMBINATION WITH VERTICILLIUM CHLAMYDOSPORIUM AGAINST MELOIDOGYNE JAVANICA
}

\author{
Muhammad Shahid ${ }^{1}$, Simon R. Gowen ${ }^{2}$, Barbara Pembroke ${ }^{2}$ \\ ${ }_{1}^{1}$ Plant Pathology Research Institute, Ayyub Agricultural Research Institute, Faisalabad, Pakistan. \\ ${ }^{2}$ Plant Protection Laboratory, Department of Agriculture, University of Reading, Reading RG6 6AT, UK.
}

ART I CLE IN F O

\section{Article history}

Received: $27^{\text {th }}$ September, 2020

Revised: $1^{\text {st }}$ November, 2020

Accepted: $27^{\text {th }}$ December, 2020

\section{Keywords}

Biological control

Crop rotation

Meloidogyne javanica

Pasteuria penetrans

Verticillium

chlamydosporium

\begin{abstract}
A B S T R A C T
The potential control of Meloidogyne javanica using Pasteuria penetrans (Pp) alone and in combination with Verticillium chlamydosporium $(V c)$ was tested in earthen pots following a cropping sequence "tomato-tomato-tomato" over three crop cycles. After the final harvesting, analysis of variance showed significant effect of treatments $(\mathrm{P}<0.01)$ regarding number of eggmasses, galls and nematode female populations. Similarly, significant effect of treatments $(\mathrm{P}<0.01)$ was also recorded in case of infected nematode females with Pasteuria and number of eggs/eggmass while no significant effect $(\mathrm{P}>0.05$ ) was observed in case of endospore production. Higher numbers of eggmasses (360) and root galling (6.2) was observed where biocontrol agents were absent (control). The treatments showed 46.58, 58.85 and 33.13 percent reduction in number of galls, eggmasses and nematodes in $P p$ alone and 43.34, 55.21 and 30.09 percent reductions in $V c+P p$ treatments respectively. Numbers of females infected with the endospores of $P$. penetrans were recorded higher in $P p-3$ alone treatment (13.2) followed by $V c+P p$ combined treatment (13.0) and maize rotated treatment (10.4) respectively. Significantly lesser number of eggmasses, galls and nematodes were recorded in pots where tomato was rotated with maize (treatment 3) compared with control. Thus rotation prevented the buildup of nematode population and resulted in a $72 \%$ decrease in numbers of eggmasses, $38 \%$ in root galling and $46 \%$ regarding female populations over the control after the final harvest. Maximum colony forming units of $V$. chlamydosporium per gram of soil were recorded after its addition to the soil. The fungus established in the soil during the first crop and soil colonization of the fungus was also observed after final crop.
\end{abstract}

Corresponding Author: Muhammad Shahid

Email: nematologistaari@yahoo.com

(C) 2020 EScience Press. All rights reserved.

\section{INTRODUCTION}

Root knot nematodes (Meloidogyne spp.) are considered to be the most pathogenic plant parasitic nematodes (Castagnone-Sereno et al., 2013; Jones et al., 2013;
Mukhtar and Kayani, 2019, 2020; Tariq-Khan et al., 2020; Trudgill and Blok, 2001) and application of chemicals for the control of these nematodes is a common practice. However, environmental problems 
associated with the use of nematacides (Thomason, 1987) have resulted in search for alternative nematode management tactics (Kerry, 1990). The biological control of nematodes with microbial agents is an alternative management approach to avoid the notorious impacts of chemicals on vegetable crop production systems and health of living beings in ecological niche (Kiewnick and Sikora, 2006). Among different biological methods, many antagonistic bacteria and fungi are being investigated and have been proved to become a potential biocontrol agent for the control of soil borne root pathogenic nematodes (Khan et al., 2008). Successful management of root-knot nematodes requires the combined effects of different strategies; thus, biological control agents are more likely to be successful when they are used in conjugation with crops that are less favorable hosts to root-knot nematodes and with other physical or cultural control practices such as solarization, fallowing and even nematicides (Bhuiyan et al., 2018; d'Errico et al., 2019; Nazir et al., 2019).

One of the good attributes of Pasteuria penetrans is its compatibility with other management practices used for suppressing root-knot nematodes (Dube and Smart Jr, 1987; Eddaoudi and Bourijate, 1998; Tzortzakakis and Gowen, 1994; Walker and Wachtel, 1988). It can be deployed as a part of integrated management of plant parasitic nematodes. Similarly, Verticillium chlamydosporium (Pochonia chlamydosporia) is a widespread fungus that parasitizes females and eggs of cyst and root-knot nematodes (Kerry et al., 1982). Both the antagonists have potential as biological control agents for Meloidogyne spp. when thoroughly incorporated through the soil (Daudi et al., 1990; De-Leij et al., 1992; Gowen and Ahmed, 1990; Madulu et al., 1994; Mukhtar et al., 2003; Rehman et al., 2009). Therefore, integration of $P$. penetrans and $V$. chlamydosporium could be an effective strategy as Pasteuria reduces total number of egg producing females while Verticillium is more effective when eggs are produced and exposed to fungus colonizing the rhizosphere. The introduction of P. penetrans into soil to reduce root invasion and egg production, together with $V$. chlamydosporium as a rhizosphere colonizer and facultative egg parasite, may improve nematode control compared with either of the organism alone.

Crop rotation with poor hosts helps in reducing nematode population. It helps in integration of biocontrol agents by suppressing nematode population and ultimately increases the efficiency of biocontrol agents. Corn, a poor host to root-knot nematodes (Alam et al., 1977) was used as rotation and proved effective in suppressing root-knot nematode population and lowering nematode infection (Huang, 1984; Sundaresh and Setty, 1977).

The present study deals with the integration of $P$. penetrans with fungal biocontrol agent $V$. chlamydosporium to ascertain the effects of the antagonists to suppress root-knot nematodes in soil and rotation of a poor host like maize to see additive effects of both biocontrol agents in reducing root -knot disease.

\section{MATERIALS AND METHODS}

The population of $M$. javanica used in the experiment was already maintained on tomato in the glasshouse of the Department of Agriculture, University of Reading, UK. An isolate of Pasteuria penetrans designated as $P p-3$ derived from M. javanica originating from South Africa, and the fungal isolate Verticillium chlamydosporium (Vc-10) obtained from Rothamsted, England were used in the experiment.

\section{Multiplication of Fungal inoculum}

The fungal inoculum was multiplied on barley by the method described by Bourne et al. (1994). Dried milled barley was washed over a $53 \mu \mathrm{m}$ aperture sieve and mixed 1:1(V/V) with coarse sand and left to dry until moist and easily friable. About $130-150 \mathrm{ml}$ of the medium, in a $250 \mathrm{ml}$ flask was autoclaved (30 min, $15 \mathrm{psi}, 120^{\circ} \mathrm{C}$ ), cooled, shaken and inoculated with $3-5$ plugs $(7 \mathrm{~mm})$ of $V$. chlamydosporium on corn meal agar. After 3 weeks of incubation at $25^{\circ} \mathrm{C}$, the colonized sand bran was washed through $250 \mu \mathrm{m}, 53 \mu \mathrm{m}$ and $10 \mu \mathrm{m}$ aperture sieves with a fine water spray to remove the sand and bran and the fungal propagules were collected on $10 \mu \mathrm{m}$ aperture sieve. The deposit was further washed to remove conidia and small hyphal fragments leaving mainly chlamydospores and blotted dry to remove extra moisture. Chlamydospores were scraped off and thoroughly mixed with fine sand (40-100 mesh; 1:10 w/w) which acted as inert carrier. A $1 \mathrm{~g}$ sub-sample of the inoculum was shaken in $9 \mathrm{ml}$ of water and the number of chlamydospores per gram sand was then estimated using a haemocytometer. Inoculum was applied @ 5000 chlamydospores/L pot in treatment 2. Initial presence of the fungus was monitored just after adding the inoculum to the soil.

\section{Multiplication of bacterial inoculum}

The bacterial inoculum was multiplied on M. javanica growing on tomato in the greenhouse by the method of 
Stirling and Wachtel (1980). Twenty plastic pots (1 L) were filled with John Inns compost as potting material. Four treatments with five replicates were arranged in a
Completely Randomized Design and kept in a growth room at temperature ranging from 10 to $30^{\circ} \mathrm{C}$. The treatments were given in Table 1.

Table 1: Description of treatments.

\begin{tabular}{clll}
\hline Treatment & First cycle & Second cycle & Third cycle \\
\hline T1 & $P p$ (Tomato) & $P p$ (tomato) & $P p$ (tomato) \\
T2 & $P p+V c$ (Tomato) & $P p+V c$ (Tomato) & $P p+V c$ Tomato) \\
T3 & $P p$ (tomato) & $P p$ (maize) & $P p$ (tomato) \\
T4 & Control (tomato) & Control (tomato) & Control (tomato) \\
\hline
\end{tabular}

Fungal inoculum was applied @ 5000 chlamydospores/L pot in all replications of treatment 2. Initial presence of the fungus was monitored just after adding the inoculum to the soil. Tomato plants cv Tiny Tim (40 days old) were transplanted singly into pots. After two weeks of transplanting, $1500 \mathrm{~J} 2 \mathrm{~s}$ of $M$. javanica encumbered with spores of $P p-3$ with a mean of 6.8 spores/J2 were inoculated per plant in treatments 1 to 3. Similarly, J2s without spores were inoculated @ 1500/plant as control in treatment no. 4. After six weeks, harvesting was made and plants were washed and fresh root weight, galling intensity and numbers of egg masses were counted. The fungal growth was monitored by taking a $1 \mathrm{~g}$ soil sample from each replicate of treatment 3. Roots were dried, chopped, macerated and incorporated back into pots. Tomato plants ( 40 days old) were transplanted into pots in all treatments except treatment 3 where it was replaced by maize as a rotation of "poor" host. During the second crop cycle, Phostrogen (14:4.4:22.4, NPK respectively) was sprayed to provide nutrients to plants. After six weeks, harvesting was done and data were recorded as described above. In the third crop cycle, tomato plants ( 6 weeks old) were transplanted in all treatments. After the final harvest, data for eggmasses, root galling, final female population, endospores per female, eggs/eggmass and infectivity of females with Pasteuria were recorded.

\section{RESULTS}

After the final harvesting, analysis of variance showed significant effect of treatments $(\mathrm{P}<0.01)$ regarding number of eggmasses, galls and nematode female populations (Table 2). Similarly, significant effect of treatments $(\mathrm{P}<0.01)$ was also recorded in case of infected nematode females with Pasteuria and number of eggs/eggmass while no significant effect ( $P>0.05$ ) was observed in case of endospore production (Table 3 ). Higher numbers of eggmasses (360) and root galling (6.2) was observed where biocontrol agents were absent (control). The treatments showed 46.58, 58.85 and 33.13 percent reduction in number of galls, eggmasses and nematodes in $P p$ alone and 43.34, 55.21 and 30.09 percent reductions in $V c+P p$ treatments respectively (Table 2). Numbers of females infected with the endospores of $P$. penetrans were recorded higher in $P p-3$ alone treatment (13.2) followed by $V c+P p$ combined treatment (13.0) and maize rotated treatment (10.4) respectively (Table 3). Significantly lesser number of eggmasses, galls and nematodes were recorded in pots where tomato was rotated with maize (treatment 3) compared with control. Thus rotation prevented the buildup of nematode population and resulted in a $72 \%$ decrease in numbers of eggmasses, 38\% in root galling and $46 \%$ regarding female populations over the control after the final harvest (Table 2,3).

Table 2. Effect of $P$. penetrans alone and in combination with $V$. chlamydosporium on numbers of eggmasses, root galling and total females of $M$. javanica (third harvest) on tomato plants.

\begin{tabular}{lccc}
\hline Treatments & Eggmasses/plant & Total females /plant & Galling/plant (0-10) \\
\hline$P p-3$ & 220 & 286 & 4.4 \\
$P p-3+V c$ & 164 & 251 & 4.0 \\
$P p-3$ (rotation) & 100 & 196 & 3.8 \\
Control & 360 & 368 & 6.2 \\
S.E.D & 15.44 & 18.97 & 0.34 \\
F-test & $\mathrm{P}<0.01$ & $\mathrm{P}<0.01$ & $\mathrm{P}<0.01$ \\
\hline
\end{tabular}

Data are means of 5 replicates 
Table 3. Effect of $P$. penetrans alone and in combination with $V$. chlamydosporium on numbers of eggs/eggmass, endospores/female and infection of females of $M$. javanica (third harvest).

\begin{tabular}{lccc}
\hline Treatments & Endospores/female $\left(\times 10^{3}\right)$ & Infected females (out of 20) & Eggs/eggmass \\
\hline$P p-3$ & 413 & 13.8 & 406 \\
$P p-3+V c$ & 421 & 13.0 & 365 \\
$P p$-3 (rotation) & 425 & 10.4 & 395 \\
Control & - & - & 446 \\
S.E.D & 23.1 & 0.57 & 27.5 \\
P value & $>0.05$ & $<0.01$ & $<0.1$ \\
\hline
\end{tabular}

Data are means of 5 replicates.

Data regarding soil colonization by fungus was recorded and maximum colony forming units of $V$. chlamydosporium per gram of soil were recorded after its addition to the soil (Table 4). The fungus established in the soil during the first crop and soil colonization of the fungus was also observed after final crop (Table 4).

\section{DISCUSSION}

Pasteuria alone proved effective in suppressing rootknot nematode infection over three crop cycles. This is due to reduced root penetration by the sporeencumbered juveniles and/or failure to form egg masses by the infected females. Many researchers have reported that movement and mobility of juveniles were reduced and their ability to locate host roots was affected when juveniles were encumbered with endospores (Ahmad and Mukhtar, 2007a, 2007b; Mukhtar and Ahmed, 2000). Reduced motility probably leads to high mortality of J2s in soil because movement is apparently essential to escape predators and unfavorable conditions (Chen et al., 1996; Mukhtar et al., 1999; Mukhtar et al., 2000). Since the reproductive system fails to develop in the infected females of root-knot nematodes, such nematodes do not lay eggs. This leads to marked reductions in the secondary infection by the second or subsequent generation juveniles (Mukhtar et al., 2002a; Mukhtar et al., 2002b; Mukhtar et al., 2013; Mukhtar et al., 2005). Overall, the nematode populations are considerably suppressed which may be beneficial to the ensuing crops. Percentage of infected females examined after third cycle showed that maximum number of females were recorded in $P p$ alone treatment.

Table 4: Number of colony forming units (CFU) of V. chlamydosporium recorded over crop cycles (1g soil).

\begin{tabular}{lc}
\hline Observations & Colony forming units \\
\hline Initial inoculum & $8,050(8.97)$ \\
First crop cycle & $42,375(10.5)$ \\
Second crop cycle & $85,675(11.3)$ \\
Third crop cycle & $67,400(11.0)$ \\
SED & $2729(0.21)$ \\
\hline
\end{tabular}

Data are means of 5 replicates (data within brackets represent log $\mathrm{x}$ transformations).

Integration of $V$. chlamydosporium with $P$. penetrans proved effective in reducing root-knot disease compared with un-amended control. $V$. chlamydosporium complemented the bacterial pathogenic potential in suppressing root-knot nematode and ultimately resulted in reduction of eggmasses, galls, and nematode female populations over three crop cycles. These findings are in agreement with those of De-Leij et al. (1992) who observed that $P$. penetrans and $V$. chlamydosporium significantly reduced $M$. incognita populations. Data regarding soil colonization by fungus were recorded and maximum colony forming units of $V$. chlamydosporium per gram of soil were recorded after its addition to the soil (Table 4). The fungus established in the soil during the first crop and soil colonization of the fungus was also observed after final crop. These results are contradictory to those of Mukhtar et al. (2003) who reported that fungus did not colonize soil and roots of subsequent crops of the sequence. The contradictory results might be due to different conditions under which experiments were conducted. Similar experiments conducted under green house and field conditions gave different results. 
Rotation of poor host (maize) suppressed significantly the multiplication of root-knot nematode which resulted in reducing numbers of eggmasses and root galling. The growth of a poor plant host in nematode infested soil for one cropping period significantly decreased the damage on a following susceptible crop, although the nematode population was not eliminated. Eggs may have survived in a diapaused stage during the growth of resistant maize, and juveniles hatched when tomato plants were planted.

P. penetrans showed tremendous potential in controlling root-knot nematodes over 3 crop cycles. Reincorporation of roots containing P. penetrans spores proved effective in suppressing the root knot nematode. It seems likely that spores of the parasite build up in the soil when the roots are incorporated in soil (Daudi et al., 1990; Gowen and Ahmed, 1990). Infected females inside the roots may also degrade and release spores in soil during plant growth, thus making the soil suppressive to nematodes.

Reduction in eggmasses, root galling and final nematode populations recorded in $P$. penetrans and $V$. chlamydosporium treatment suggest if these bio-control agents parasitize different stages of the nematode life cycle and they might have a complementary effect in suppressing the Meloidogyne populations. Both the organisms reduced reproductive potential of the nematode. $V$. chlamydosporium was the most effective after the first harvest when most eggmasses were produced in the rhizosphere and the fungus could colonize the eggmasses. Later when eggmasses were produced within galls and were protected from the fungus, $P$. penetrans spores liberated from disintegrating females might have produced a degree of secondary infection. These findings are in agreement with De-Leij et al. (1992) who observed that P. penetrans and $V$. chlamydosporium significantly reduced the population of root-knot nematode, $M$. incognita. There was no statistically significant difference among females of nematodes parasitized by P. penetrans in the treatment where both biocontrol agents were applied. This shows that $V$. chlamydosporium does not affect the hostparasite relationship of nematode and bacterium.

$V$. chlamydosporium has shown tremendous potential to establish in soil over crop cycles. It has a good attribute of a successful biocontrol agent for soil borne pathogens as it is able to grow, survive and proliferate. Being a facultative parasite, it can grow even in the absence of the nematode host. The successful establishment of $V$. chlamydosporium from application of chlamydospores without an energy source simplifies its use in microplot experiments. However, the fungal growth reduced after third cycle as its growth declines rapidly after three months in the soil due to absence of energy source (Kerry et al., 1993).

Lesser eggmasses and root galling found in the maize rotation treatment reflects that during the second crop cycle (in the presence of maize host), nematodes could not invade the roots and moved in soil to locate penetration sites. J2s might have acquired spores and in the third crop cycle, invaded tomato roots, thus ultimately resulting in fewer eggmasses and root galling. When a nematode population is reduced by checking multiplication by growing a poor host, the small numbers of nematodes found might acquire more spores and this will help in reducing invasion due to high spore burden (Brown and Smart, 1985; Davies et al., 1988; Davies et al., 1991; Stirling, 1981). Thus rotation helps $P$. penetrans to suppress root-knot populations more effectively in subsequent crop cycles. The lower level of parasitism recorded in the third treatment indicated that the nematode-resistant host did not favor Pasteuria development in the soil. The effect of a nematoderesistant host was to prevent the increase of the parasite and this resulted in poor multiplication of Pasteuria as the bacterium is density dependent (Chen et al., 1996).

It is concluded from the present study that Pasteuria was been found effective when integrated with $V$. chlamydosporium or rotation and should be used as a part of an integrated approach in the management of root-knot nematodes.

\section{AUTHOR CONTRIBUTION}

MS and SRG designed the study, MS executed the experiment, collected data, and wrote the manuscript, SRG supervised the work, BP helped in technical work and analysis of data, SRG and BP edited the manuscript.

\section{CONFLICT OF INTEREST}

The authors declare no conflict of interest.

\section{REFERENCES}

Ahmad, R., Mukhtar, T., 2007a. Investigations on the management of Meloidogyne javanica by Pasteuria penetrans isolates over three crop cycles of eggplant. Pakistan Journal of Nematology 25, 157164.

Ahmad, R., Mukhtar, T., 2007b. Root invasion of different plant hosts by juveniles of Meloidogyne species 
encumbered with Pasteuria penetrans spores. Pakistan Journal of Nematology 25, 199.

Alam, M.M., Saxena, S.K., Khan, A.M., 1977. Influence of different cropping sequences on soil populations of plant parasitic nematodes. Nematologia Mediterranea 5, 65-72.

Bhuiyan, S.A., Garlick, K., Anderson, J.M., Wickramasinghe, P., Stirling, G.R., 2018. Biological control of root-knot nematode on sugarcane in soil naturally or artificially infested with Pasteuria penetrans. Australasian Plant Pathology 47, 45-52.

Bourne, J.M., Kerry, B.R., De Leij, F.A.A.M., 1994. Methods for the study of Verticillium chlamydosporium in the rhizosphere. Journal of Nematology 26, 587591.

Brown, S.M., Smart, J.G.C., 1985. Root penetration by Meloidogyne incognita juveniles infected with Bacillus penetrans. Journal of Nematology 17, 123126.

Castagnone-Sereno, P., Danchin, E.G.J., Perfus-Barbeoch, L., Abad, P., 2013. Diversity and evolution of rootknot nematodes, genus Meloidogyne: new insights from the genomic era. Annual Review of Phytopathology 51, 203-220.

Chen, Z.X., Dickson, D.W., McSorley, R., Mitchell, D.J., Hewlett, T.E., 1996. Suppression of Meloidogyne arenaria race 1 by soil application of endospores of Pasteuria penetrans. Journal of Nematology 28, 159-168.

d'Errico, G., Marra, R., Crescenzi, A., Davino, S.W., Fanigliulo, A., Woo, S.L., Lorito, M., 2019. Integrated management strategies of Meloidogyne incognita and Pseudopyrenochaeta lycopersici on tomato using a Bacillus firmus-based product and two synthetic nematicides in two consecutive crop cycles in greenhouse. Crop Protection 122, 159164.

Daudi, A.T., Channer, A.G., Ahmed, R., Gowen, S.R., 1990. Pasteuria penetrans as a biocontrol agent of Meloidogyne javanica in the field in Malawi and in microplots in Pakistan, Proceedings of the British Crop Protection Conference, Pests and Diseases, pp. 253-257.

Davies, K.G., Kerry, B.R., Flynn, C.A., 1988. Observations on the pathogenicity of Pasteuria penetrans, a parasite of root-knot nematodes. Annals of Applied Biology 112, 491-501.

Davies, K.G., Laird, V., Kerry, B.R., 1991. The motility, development and infection of Meloidogyne incognita encumbered with spores of the obligate hyperparasite Pasteuria penetrans. Revue de Nématologie 14, 611-618.

De-Leij, F.A.A.M., Davies, G., Kerry, R., 1992. The use of Verticillium chlamydosporium Goddard and Pasteuria penetrans (Thorne) Sayre \& Starr alone and in combination to control Meloidogyne incognita on tomato plants. Fundamentals and Applied Nematology 15, 235-242.

Dube, B., Smart Jr, G.C., 1987. Biological control of Meloidogyne incognita by Paecilomyces lilacinus and Pasteuria penetrans. Journal of Nematology 19, 222-227.

Eddaoudi, M., Bourijate, M., 1998. Comparative assessment of Pasteuria penetrans and three nematicides for the control of Meloidogyne javanica and their effect on yields of successive crops of tomato and melon. Fundamental and Applied Nematology 21, 113-118.

Gowen, S.R., Ahmed, R., 1990. Pasteuria penetrans for control of pathogenic nematodes. Aspects of Applied Biology 24, 25-32.

Huang, S.P., 1984. Cropping effects of marigolds, corn, and okra on population levels of Meloidogyne javanica and on carrot yields. Journal of Nematology 16, 396-398.

Jones, J.T., Haegeman, A., Danchin, E.G.J., Gaur, H.S., Helder, J., Jones, M.G.K., Kikuchi, T., ManzanillaLópez, R., Palomares-Rius, J.E., Wesemael, W.M.L., 2013. Top 10 plant-parasitic nematodes in molecular plant pathology. Molecular Plant Pathology 14, 946-961.

Kerry, B.R., 1990. An assessment of progress toward microbial control of plant-parasitic nematodes. Journal of Nematology 22, 621-631.

Kerry, B.R., Crump, D.H., Mullen, L.A., 1982. Studies of the cereal cyst-nematode, Heterodera avenae under continuous cereals, 1975-1978. II. Fungal parasitism of nematode females and eggs. Annals of Applied Biology 100, 489-499.

Kerry, B.R., Kirkwood, I.A., De Leij, F.A.A.M., Barba, J., Leijdens, M.B., Brookes, P.C., 1993. Growth and survival of Verticillium chlamydosporium Goddard, a parasite of nematodes, in soil. Biocontrol Science and Technology 3, 355-365.

Khan, Z., Kim, S.G., Jeon, Y.H., Khan, H.U., Son, S.H., Kim, Y.H., 2008. A plant growth promoting 
rhizobacterium, Paenibacillus polymyxa strain GBR-1, suppresses root-knot nematode. Bioresource Technology 99, 3016-3023.

Kiewnick, S., Sikora, R.A., 2006. Biological control of the root-knot nematode Meloidogyne incognita by Paecilomyces lilacinus strain 251. Biological control 38, 179-187.

Madulu, J.D., Trudgill, D.L., Phillips, M.S., 1994. Rotational management of Meloidogyne javanica and effects on Pasteuria penetrans and tomato and tobacco yields. Nematologica 40, 438-455.

Mukhtar, T., Ahmad, R., Gowen, S.R., 1999. Effect of a cropping sequence on the management of Meloidogyne javanica and Pasteuria penetrans build up., Proceedings of 2nd Conference of Plant Pathology, pp. 175-178.

Mukhtar, T., Ahmad, R., Javed, N., 2002a. Efficacy of Pasteuria penetrans and Verticillium chlamydosporium in the biological control of Meloidogyne javanica. Pakistan Journal of Phytopathology 14, 79-83.

Mukhtar, T., Ahmad, R., Khan, S.M., 2000. Attachment of Pasteuria penetrans spores to the cuticle of Meloidogyne javanica as affected by leaf extracts of some plants. Pakistan Journal of Phytopathology 12, 53-55.

Mukhtar, T., Ahmad, R., Mukhtar, N., 2002b. Effect of antagonistic plants on the biological control of Meloidogyne javanica by Verticillium chlamydosporium. Pakistan Journal of Phytopathology 14, 74-78.

Mukhtar, T., Ahmed, R., 2000. Combined efficacy of Pasteuria penetrans and leaf extracts on the biocontrol of Meloidogyne javanica on tomato. Pakistan Journal of Phytopathology 12, 56-61.

Mukhtar, T., Hussain, M.A., Kayani, M.Z., 2013. Biocontrol potential of Pasteuria penetrans, Pochonia chlamydosporia, Paecilomyces lilacinus and Trichoderma harzianum against Meloidogyne incognita in okra. Phytopathologia Mediterranea 52, 66-76.

Mukhtar, T., Kayani, M.Z., 2019. Growth and yield responses of fifteen cucumber cultivars to rootknot nematode (Meloidogyne incognita). Acta Scientiarum Polonorum Hortorum Cultus 18, 4552.

Mukhtar, T., Kayani, M.Z., 2020. Comparison of the damaging effects of Meloidogyne incognita on a resistant and susceptible cultivar of cucumber. Bragantia 79, 83-93.

Mukhtar, T., Pervaz, I., Ahmad, R., Khan, H.U., 2003. Comparative efficacy of different bio-control agents against Meloidogyne javanica. Pakistan Journal of Phytopathology 15, 5-8.

Mukhtar, T., Pervaz, I., Ahmad, R., Khan, H.U., 2005. Management of Meloidogyne javanica by cropping sequence and effects on Pasteuria penetrans. Pakistan Journal of Nematology 23, 173-180.

Nazir, K., Mukhtar, T., Javed, $H_{.}$., 2019. In vitro effectiveness of silver nanoparticles against rootknot nematode (Meloidogyne incognita). Pakistan Journal of Zoology 51, 2077-2083.

Rehman, A.U., Javed, N., Ahmad, R., Shahid, M., 2009. Integration of bio-products and Pasteuria penetrans for the management of root-knot nematode over three crop cycles of tomato. Pakistan Journal of Nematology 27, 325-336.

Stirling, G.R., 1981. Effect of temperature on infection of Meloidogyne javanica by Bacillus penetrans. Nematologica 27, 458-462.

Stirling, G.R., Wachtel, M.F., 1980. Mass production of Bacillus penetrans for the biological control of root-knot nematodes. Nematologica 26, 308-312.

Sundaresh, H.N., Setty, K.G.H., 1977. Crop rotation as an effective and practical means of controlling rootknot nematode (Meloidogyne incognita Chitwood). Current Research 6, 157-158.

Tariq-Khan, M., Mukhtar, T., Munir, A., Hallmann, J., Heuer, H., 2020. Comprehensive report on the prevalence of root-knot nematodes in the Poonch division of Azad Jammu and Kashmir, Pakistan. Journal of Phytopathology 168, 322-336.

Thomason, I.J., 1987. Challenges facing nematology: Environmental risks with nematicides and the need for new approaches. Society of Nematologists, Inc. Maryland, 469-476.

Trudgill, D.L., Blok, V.C., 2001. Apomictic, polyphagous root-knot nematodes: exceptionally successful and damaging biotrophic root pathogens. Annual Review of Phytopathology 39, 53-77.

Tzortzakakis, E.A., Gowen, S.R., 1994. Evaluation of Pasteuria penetrans alone in combination with oxamyl, plant resistance and solarization for control of Meloidogyne spp. on vegetables grown in greenhouses in Crete. Crop Protection 13, 455462. 
Walker, G.E., Wachtel, M.F., 1988. The influence of soil solarisation and non-fumigant nematicides on infection of Meloidogyne javanica by Pasteuria penetrans. Nematologica 34, 477-483. 